NBER WORKING PAPER SERIES

THE ROLE OF MACROECONOMIC

FACTORS IN GROWTH

Stanley Fischer

Working Paper No. 4565

\author{
NATIONAL BUREAU OF ECONOMIC RESEARCH \\ 1050 Massachusetts Avenue \\ Cambridge, MA 02138 \\ December, 1993
}

I am grateful to Michael Bruno, Jose de Gregorio, Robert King, Ken Rogoff and Sweder van Wijnbergen for helpful suggestions and comments, to participants in a Hebrew University seminar, especially Michael Beenstock and Giora Hanoch, for suggestions, and to Ruth Judson for excellent research assistance. This paper is part of NBER's research programs in Economic Fluctuations and Monetary Economics. Any opinions expressed are those of the author and not those of the National Bureau of Economic Research. 


\title{
THE ROLE OF MACROECONOMIC FACTORS IN GROWTH
}

\begin{abstract}
Using a regression analog of growth accounting, I present cross-sectional and panel regressions showing that growth is negatively associated with inflation, large budget deficits, and distorted foreign exchange markets. Supplementary evidence suggests that the causation runs from macroeconomic policy to growth. The framework makes it possible to identify the channels of these effects: inflation reduces growth by reducing investment and productivity growth; budget deficits also reduce both capital accumulation and productivity growth. Examination of exceptional cases shows that while low inflation and small deficits are not necessary for high growth even over long periods, high inflation is not consistent with sustained growth.
\end{abstract}

\author{
Stanley Fischer \\ Department of Economics, E52-373 \\ Massachusetts Institute of Technology \\ Cambridge, MA 02139 \\ and NBER
}




\title{
THE ROLE OF MACROECONOMIC FACTORS IN GROWTH
}

\author{
Stanley Fischer'
}

It is now widely accepted that a stable macrocconomic framework is necessary though not sufficient for sustainable economic growth. ${ }^{2}$ In this paper I present international cross-sectional regression evidence that supports the view that growth is negatively associated with inflation, and positively associated with good fiscal performance and undistorted foreign exchange markets. I also present evidence suggesting that the causation runs in part from good macroeconomic policy to growth.

The view that a stable macroeconomic framework is conducive to growthis also supported by much striking non-regression evidence. In Latin America, the recovery of economic growth in Chile and Mexico was preceded by the restoration of budget discipline and the reduction of inflation. ${ }^{3}$ By contrast, the ongoing growth crisis in Brazil coincides with high inflation punctuated by stabilization attempts and continued macroecononic instability. The fast growing countries of East Asia have generally maintained single or low dauble-digit inflation, have for the most part avoided balance of payments crises, and when they have had them $-\cdot$ as for instance in Korea in 1980 -- moved swiftly to deal with them. The lessons of the casc study evidence amassed in the major World Bank research project headed by Little, Cooper, Corden and Rajapatirana (1992), summarized in Corden (1991), support the conventional view. The notion that macroeconomic stability is 1101 sufficient for growth is supported by evidence from Africa, where most of the countries of the franc zone have grown slowly since 1980 despite low inflation.

This paper considerably extends and strengthens results presented in Fischer (1991). In thal paper, I

\footnotetext{
${ }^{2}$ Department of Economics, MIT, and Research Associate. NBER. This paper is part of the World Bank's Growlh Project. I am grateful to Michael Bruno, Jose de Gregorio, Robert King, Ken Rogoff and Sweder van Wijnbergen for helptul suggestions and comments, to participants in a Hebrew University seminar, especially Michacl Becnstock and Giora Hastoch, for suggestions, and to Ruth Judson for excellent research assistance.

${ }^{2}$ See World Bank (1989, 1990, 1992).

${ }^{3}$ However in both cases it look several years to reduce inflation to the moderate, $15-30$ percitul. range.
} 
used the conventional approach of adding macroeconomic variables to the basic growth regression. In this paper, in Sections III through V, I develop an altemative approach due to Victor Elias (1992), a regression analog of growth accounting. I present both pure cross-scctional regressions as well as panel regressions, which exploit the time series as well as cross-sectional variution in the data. I also explore non-lintarities in the relationship between inflation and growth. In Section V1 I discuss the issue of the causality belwcen intlation and economic growth. Then in Section VII I identify and discuss some apparent exccptions, countrics where high growth took place despite high inflation and/or large deficits, and conclude that the statement that macroeconomic stability is necessary for sustainable growth is too strong, but that the statemcnt that macroeconomic stability is conducive to sustained growth remains accurate.

The paper opens with a discussion in Section 1 of the notion of a stable macroeconomic framework, and of the theoretical considerations linking growth to macroeconomic policies. In Section II I briefly review rccent evidence on the link between macroeconomic conditions and growth, most of it based on the standard mixed regression which includes among its regressors the rate of investment.

\section{DEFINITIONS AND THEORETICAL CONSIDERATIONS}

In practice the concept of a stable macroeconomic framework is used to mean a macrocconomic policy environment that is conducive to growth. The macroeconomic framework can be described as stable when inflation is low and predictable, real interest rates are appropriate, fiscal policy is stablc and sustainable, the real exchange rate is competitive and predictable, and the balancc of payments situation is perceived as viable." This definition goes beyond the stability of macroeconomic policy variables to include also the criterion that policyrelated variables are at levels conducive to growth.

Of the tive criteria specified in the prceeding definition, only low and stable inflation is readily quantifiable. None of the specified variables is directly controllable by policy, and each should optimully vary

tNon-linearities in the inflation-growth relationship have also been explored by Levine and Zervos (1992).

${ }^{5}$ Tbis definition is based on World Bank (1990a), p4.

${ }^{5}$ With regard to quantification of the other four variables: Measures of the fiscal deficit provide sonle information about Iiscal policy; however it is difficult to characterize fiscal policy by a single variable (Mackenzie, 1989). and intemational fiscal date aro poor. Estimates of sustainable deficits could in principlo be caiculated along the lines of Hamilton and Flavin (1986), but that level of deteil would require a much more exiensive study than can be carried out in the current project. The 
in response to shocks. Given the praciical difficulty of defining and measuring the stability of the macroeconomic framework, or the optimal or appropriate inflation rate, real interest rate, real cxchange rate, and so forth, I instead proceed by specifying indicators of macroeconomic policy.

The basic indicators of macroeconomic policy are the inflation rate, the budget surplus or deficit, and the black market exchange premium. I shall use the inflation rate as the best single indicator of the conduciveness of macroeconomic policies to growth," and the budget surplus as the second basic indicator.

In essence, the inflation rate serves as an indicator of the overall ability of the government to manage the economy. Since there are no good arguments for very high rates of inflation, a government that is producing high inflation is a government that has lost control. All governments anuounce that they aim for low inflation, and the macroeconomic situation in any medium or high inflation economy can therefore be expected to change. While there are economies in which inflation remains at moderate levels for prolonged periods (Dornbusch and Fischer, 1993), economic agents in a high or medium inflation economy have to expect an attack -- typically many attacks -- on inflation at some point.

Countries may for a long time succed in maintaining low and stable inflation through policies thut are not ultimately sustainable. Such countries, for instance those in the franc zone, may face fiscial or balance of payments crises that could necessitate sharp changes in macroeconomic policy and that ccrtainly increase macroeconomic uncertainty. The fiscal deficit is a good, though imperfect, indicator of such an unsustainable situation. In addition, as discussed below, the deficit is likely to affect growth through its effects on capital accumulation.

I use the black market premium on forcign exchange as an indicator of the sustainability and appropriateness of the exchange rate. The black market prenium is a good indicator of a distortcd or controlled market for foreign exchange, but is less good as an indicator of the unsustainability of the cxchange rate, since an exchange rate may be overvalued and unsustainable even when there is no black market premium.

Most developing countries experienced major terms of trade shocks during the period over which the

competitiveness of the real exchange rate could in principle be estimated by its implications for current and future levels of the current accounl, while the appropriateness of the real interest rale is difficult to specify.

'The potential links between inflation and growth are discussed and developed in Fischer (1983) and by inplication in Fischer and Modigliani (1978), and are taken up below. 
regressions in this paper are estimated. The terms of trade are included as a separate exogenous determinant of macroeconomic performance."

The usual emphasis on the stability of the macroeconomic framework (rather than its conduciveness to growth) suggests that the main reason macroeconomic factors matter for growth is through uncertainty. There are two main channels through which uncertainty could affect growth. First, policy-induced macroeconomic uncertainty reduces the efficiency of the price mechanism, as in the classic Lucas (1973) contribution. This uncertainty, associated with high inflation or instability of the budget or current account, can be expected to reduce the level of productivity, and, in contexts where the reallocation of factors is part of the growth process, also the rate of increase of productivity. Second, temporary uncertainty about the macroeconomy tends to reduce the rate of investment, as potential investors wait for the resolution of the uncertainty before committing themselves (Pindyck and Solimano, 1993). This channel suggests that investment would be lower at times when uncertainty is high, and its presence should therefore be more noticeable in the time series than cross-sectional data. Capital flight, which is likely to increase with domestic instability, provides another mechanism through which macroeconomic uncertainty reduces investment in the domestic economy.

The variability of inflation might serve as a more direct indicator of the uncertainty of the macroeconomic environment. However, the inflation rate and the variance of the inflation rate are highly correlated in the cross-section, making it difficult to disentangle the effects on growth of the level of inllation from the effects of uncertainty about inflation. By adding a time series measure of inflation vurivbility to the panel regressions, 1 attempt in this paper to to bring further evidence to bear on the level-uncertainty distinction, but with limited success. ${ }^{10}$

The 1950 s and 1960 s growth theory literature on inflation and growth emphasized the positive impact of inflation on capital accumulation that occurs as a result of the portfolio shift away from money when the rate

\footnotetext{
${ }^{8}$ Date sources are described in the appendix.

${ }^{9}$ Solimano (1989) prewents time series evidence supporting this relationship.

${ }^{10}$ Aizen man and Marion (1991) attempt to quantify policy uncertainty by estimaling autoregressive processes for policy variables and using the standard deviations of policy surprises as a measure of uncertainty. This is a pronising approach, which however does not distinguish contemporaneous variability caused by responses to exogenous shouks from purcly random
} vanability. 
of return on money falls, the Mundell-Tobin effect. Subsequent contributions, noting various complensentarities between real balances and capital - whether through the production function or because of a cash-in-advance constraint -- predicted that higher inflation would reduce capital accumulation." Similarly, all the costs of inflation detailed in Fischer and Modigliani (1978) -- including the impact of inflation on the taxation of cispita] -- would imply a negative association between the level of income and inflation, and through the new growth theory mechanisms, between inflation and growth. It is also possible that the relationship between inflation and growth is non-linear.

Tuming to the other macroeconomic indicators: The budget surplus should be positively associated with capital aceumulation. There are again two reasons. The first is crowding out. The second is that, like the inflation rate, the deficit serves as an indicator of a government that is losing control of its actions.

An increase in the black market exchange premium is an indicator of expectations of depreciation of the exchange rate and foreign exchange rationing. This suggests that capital accumulation and the black market premium are likely to be negatively related. One influence in the opposite direction arises from the fact that when foreign exchange access is controlled, there is frequently preferential treatment for the import of investment goods.

Of course, each of these indicators has its shortcomings as a policy measure. In the short run, neither the inflation rate nor the budget deficit is unaffected by the growth rate. For instance, a supply shock will both reduce the growth rate and raise the inflation rate; and given government spending, a reduction in growth will increase the deficit. Two main types of regressions are reported in this paper. In the cross-sectional regressions, the period average (usually 1961-88) growth rate or other dependent variable for each country is regressed on period average values of such right hand side variables as inflation and the budget deficit. In the pane! regressions, similar regressions are run using both the time series variation within each country and tlie crosssectional variation. The problem of reverse causation is more likely to arise in the panel regressions. In principle, the use of instrumental variables can deal with the endogeneity problem, but in practice appropriate instruments are difficult to find. The endogencity problem is less severe in the cross-sectional regrcssions,

\footnotetext{
${ }^{11}$ For references to the lilerature through 1983, sce Fischer (1983).
} 
where the Iength of period is more than 25 years. Over such long periods, the average rates of inflation and the deficit are more likely to be determined by the govemment's basic policy stance than by the short-run association between shocks and the endogenous policy indicators. In addition, I use prior knowledge, the liming of the 1973 oil shock, to break the period down into one in which demand shocks predominated (pre-1973), and one in which there were many supply shocks, and show that the results based on the pre-1973 data also support the basic contention of this paper.

\section{EXISTING EMPIRICAL EVIDENCE}

Beyond the evidence of the examples presented in the introduction, the simple statistical evidence supports the basic proposition that macroeconomic stability is conducive to growth. Inflation in tast-growing Asia is well below the rates of price increase in slower-growing Africa and Latin America (Table 1), and across the three periods shown in Table 1, inflation in each area has moved inversely with growth. ${ }^{13}$ Levine and Renelt (1992) show that high growth countries are also lower inflation countries, have smaller governments, and lower black market exchange rate premia--the latter reflecting disequilibria in the official forcign exchange markets.

The large volume of empirical work inspired by the new growth theory consists largely of cross-country regressions, typically using the Summers-Heston (1988) 1CP data. ${ }^{13}$ Levine and Renelt (1992), list forty crosssectional growth studies published between 1980 and 1990.' Their paper starts from a basic regression in which per capita real income growth (GYP, from the World Bank data base) is regressed on Summers-Heston

\footnotetext{
${ }^{12}$ The World Bank SAVEM tables from which Table $I$ is derived present more regional detail than does Table 1 . For both South Asie and East Asia, growth and inflation change in the same direction between 1965-73 and 1973-80. For the Middle East and North Africa, growth and inflation exhibit the sanje general correlation as is seen in Table $I$, that is, they move in opposite directions from period to period. (I should also nole that a table similar 10 Table 1 is presented in Fischer (1991). The inflation rate for Asia in that table (for which the first period is 1960-73) is shown as increasing from period to period, with an averege of only 2 percent for 1960-73. Both tables are taken from the same source, and I am unable to account for the different patterns of Asian inflation, though they may arise from chan ges in country coverage and dala revisions or possibly a transcription etror.)

${ }^{13}$ For examples, see Barro (1991) and the many studies listed in Levine and Renelt (1992).

${ }^{14}$ Their list is necessarily incomplete; in particular, it does not include the comparative cross-country analysis by Adelman and Morris (1988), which is based on work dating back to the 1960s. Several other earlier cross-country studies are listed by Chenery. (Chapter 2 in Chenery, Robinson and Syrquin (1986), (p.27)). Reynolds (1986, p.101) also prescists a crosssectional growth regression, despito his general preference for time-series studies.
} 
initial real income (RGDP60), population growth (GN), the 1960 rate of secondary school enrollment (SEC), and the share of investment in GDP (INV). The regression is estimated on a sample of 101 countries, over the period 1960-89:

(1)GYP $=-0.83-0.35 \mathrm{RGDP} 60-0.38 \mathrm{GN}+3.17 \mathrm{SEC}+17.5 \mathrm{INV}$

$(-0.98)(-2.50) \quad(-1.73) \quad(2.46) \quad(6.53)$

$$
\overline{\mathrm{R}}^{2}=0.46 ; \quad \text { l-statistics in parentheses }
$$

Growth is robustly (in the Leamer sense) related to initial income and to investment, but not to the other variables.

When Levine and Renelt extend the analysis to include a variety of other variables, they find, first, that several measures of economic policy are related to long-run growth; and second, that the relationship between growth and almost every particular macroeconomic indicator other than the investment ratio is fragile. The strongest results are that investment in physical capital, and either the level or the rate of change of human capital, increase the rate of growth.

In Fischer (1991), 1 extended the basic Levine-Renell growth equation to include macroeconomic indicators. Per capita growth is negatively associated with inflation and positively associated with the budget surplus as a share of GNP. While the coefficients on inflation and the budget surplus are statistically significant, the negative coefficient on external debt is not, in a sample that includes all countries for which data were available. ${ }^{\text {s }}$

As discussed in Section 1, these macroeconomic indicators cannot be regarded as truly exogenous. Instruments are difficult to find; for instance, such candidates as measures of political instability not only cause but also are caused by inflation. ${ }^{16}$ Given the difficulties of choosing instruments, 1 do not pursue instrumentul variables regressions in the remainder of this paper, but address the issue of endogeneity in Section Vl.

The negative relationship between inflation and eeonomic growth has been found also in other papers,

${ }^{15}$ It can be argued that the developing countrics are sufficiently and systcmatically dilferent from the industrialised countries that the latter should be excluded from the regressions. While it is easy to agree with uis view al the extrenics, it is hard to know where to draw the line, and I therefore worked mosily with all countries for which there were data. For some regressions (not reported here), 1 excluded all countries that in 1970 had an income level above Italy's; if anything, this gave stronger results with respec1 to macroeconomic variables. particularly the debt.

\footnotetext{
${ }^{16}$ Results oblained using different sets of instruments are presented in Fischer (1991).
} 
for instance in Fischer (1983), de Gregorio (1993), and Gylfason (1991). To deal with the endogeneity of inflation, Cukierman et al (1992) use measures of central bank independence as an instrument for inflation. They conclude that, even after instrumenting with the betler indicators of central bank independence, there remains a significant negative relationship betwcen inflation and economic growth. De Long and Summers (1992) likewise implicitly use the degree of cenlral bank independence as an instument for inflation and argut that lower inflation is associated with higher growth.

Levine and Zervos (1992), returning to the questions examined by Levine and Renelt, show that an inflation variable has a significant coefficient when added to the basic growth equation, but that the relationship is not robust, and can be traced to several high inflation countries. They also examine possible nonlincarities in the relationship between inflation and growth. Their final innovation is to create an index of macroceonomic policy, a function of the rate of inflation and the budget deficit, and to show that growth is positively associated with better (low inflation, larger budget surplus) macroeconomic policy indicators. Easterly and Rebelo (1992) find a consistent negative relationship between growth and budget deficits.

The simple correlations suggested by Table 1 , and the more detailed empirical work that builds on equation (1), thus support the view that a stable macrocconomic framework is conducive to growth. 


\section{I. INTERPRETING THE EVIDENCE}

The basic growth regression (1) includes the investment rate as a regressor. The effects of macroeconomic policy variables are usually studied by adding them as right hand side variables to the basic regression. The resultant regression therefore prcsents severe difficulties of intcrpretation when used to examine the role of policy variables or other indicators in the growth process. Presumably the interpretation of such equations is that, conditional on the rate of investment, other variables affect growth. But it is hard to conceive of variables that would not affect growth through their effect on investment as well as through other roules, mostly the rate of productivity increase -- and this is especially true of macroeconomic variables.

Recognizing this, Вапо (1991) also presents investment equations, as does Fischer (1991). Nonetheless, since some of the same variables explain both growth and investment, the policy variableaugmented growh regression has no straighforward interpretation. Rather these seem to be mongrel regressions, born out of a legitimate study of convergence and the desire to study the effects of policy on growth."

In this section 1 use a simple alternative to the mixed regression, a production function-based approach pioneered by Victor Elias (1992). The approach is a regression analog of growth accounting, which helps identify the channels through which macroeconomic variables affect economic growth. As a matter of accounting, growth can be attributed to increases in supplies of factors, and to a residual productivity category, reflecting changes in the efficiency with which factors are used. The approach is to examine the rclationships between growth and macroeconomic variables, and then between the macroeconomic variables and changes in both the supplies of factors, and the residual, or productivity.

Consider the production function

(2) $Y_{t}=F\left(K_{1}, L_{1}, H_{n} A_{2}\right)$

where $K, L$ and $H$ are physical capital, raw labor, and human capital respectively, and $A_{1}$ is an overall efliciency factor, including not only the level of technology, but also for example representing the quality of goverment management of the economy, or institutional factors. Differentiating (2), we obtain the conventional growth accounting equation:

${ }^{17}$ Some of the more recent papers, for instance Cukierman et al (1992), and Levine and Zervos (1992), do not include investment in the equation that also includes inflation, but do include other conditioning variables such as initial real income. 
(3) $Y / Y=a_{1}(K / K)+a_{2}(L / L)+a_{3}(H / H)+a_{4}(A / A)$

where $a_{i}$ is the elasticity with respect to argument $i$ in equation

(2). The product $a_{4}(A / A)$ will be referred to as the productivity residual.

Macroeconomic factors can in principle aflect economic growth through all four factors on the right hand side of the growth accounting equation (3). The standard procedure of adding macroeconomic varjables to a growth regression that already includes some of the right-hand side variables thus implicitly assumes that that policy variable does not affect the other included variables, and affects growth only through its impact on the right-hand side variables in (3) not explicilly included in the regression, typically the productivity residual. 


\section{Productivity Residuals.}

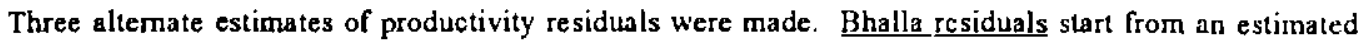
panel regression equation like (3), with the three factor inputs included explicitly. The data are those provided by Surjit Bhalla through the Bank's 1991 World Development Report (WDR) database. The Bhalla panel regression implies productivity residuals for each country for each year; the mean productivity residual for each country, plus the dummy for its region, is an estimate of the average rate of productivity increase for that country, on the (maintained) assumption that the production function for each country is the same up to the productivity variable. ${ }^{18}$

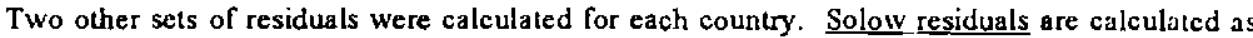

(4) $\mathrm{RES}_{\mathrm{is}}=\mathrm{ZGDP}_{\mathrm{it}}-0.4 \mathrm{ZKAP}_{\mathrm{it}}-0.6 \mathrm{ZLAB}_{\mathrm{it}} \mathrm{i}=1, \ldots, 68$

$\mathrm{t}=1961$ to 1988

Mankiw-Romer-Weil residuals are calculated as

(5) REMRW $_{\mathrm{it}}=\mathrm{ZGDP}_{\mathrm{u}}-0.333 \mathrm{ZKAP}_{\mathrm{it}}-0.333 \mathrm{ZLAB}_{\mathrm{u}}-0.333 \mathrm{ZED}_{\mathrm{tt}}$

$$
i=1, \ldots, 68 ; t=1961 \text { to } 1988 \text {. }
$$

Calculation of the Solow residuals imposes a common Cobb-Douglas production function in which the share of capital is somewhat higher than in the industrialized countries, as it generally is estimated to be in developing countries. Mankiw-Romer-Weil residuals are calculated imposing coefficients used in their 1992 paper.

The productivity residuals constructed by these three methods are very highly correlated in the lime serics for each country (with pairwise $\mathrm{R}^{21}$ s all cxceeding 0.98 ), and we therefore use the Solow residuals in the remainder of the paper.

Table 2 presents the minima and maxima of the mean rates of Solow productivity growth calculaled for

${ }^{18}$ The Bhalla production function estimated on the full panel by GLS is

(FI) $\mathrm{ZGDP}=0.398 \mathrm{ZKAP}+0.440 \mathrm{ZLAB}+0.012 \mathrm{ZED}+\mathrm{RD}$

(14.25) (3.53) (0.38)

$N=1912 ;$ t-staliatics in parentheses.

ZGDP is the growth rate of real GDP (in 1980 prices); ZKAP is the growth rate of capital; ZLAB is the growth rate of the lubor force; and ZED is the growth rate of the educational stock in the labor force (calculaled as the product of the average years of education of the adult population and the labor force). Regional dummies (RD $)$ are included for the five World Bank regions s1 of $199 \mathrm{I}$ and the OECD. Coefficients are: EMENA (Europe. Middle East and North Africa), 0.011; LACAR (Latin America and Caribbean) 0.002; AFRIC, -0.004; EASIA 0.006; SASIA 0.001; and OECD 0.007. These coeflicients are small in absolute value and only those on EMENA and OECD are significantly different from zero. 
each of the five 1991 World Bank regions and the OECD. These estimates raise obvious questions about the underlying Summers and Heston data, or perhaps the input data. When similar calculations were made using World Bank income data, the productivily residuals looked more plausible. For inslance Pakistan had the highest rate of productivity growth in South Asia, and Congo had the highest in Africa. However since the Summers-Heston income data are widely used, 1 chose to work with those, leaving the investigation of the apparent anomalies in Table 2 for later research. The difference between the maximum (Brazil) and minimum (Haiti) rates of productivity increase is very large, 6.7 percent per annum. Even the range across regions -- 2.19 percent -- is large.

\section{RESULTS IN THE GROWTH ACCOUNTING FRAMEWORK}

Cross-sectional regressions for the largest possible number of countries on single macroeconomic indicator variables are presented in Table 3. 19 These are regressions in which there are no regional dummies, and only a constant in addition to the variable indicated. However, the coefficients change very little when regional dummies are added. The inflation rate, budget surplus, black market exchange premiun, and the standard deviation of inflation, are each individually significantly correlated with the growth rate. ${ }^{20}$

Regression (11) is included for completeness, though there is only a small number of countries for which the full set of data is available. ${ }^{21}$ The coefficients on the budget surplus and the black market exchange premium are strongly significant. ${ }^{2}$

This first cross-sectional look at correlations between growth and macroeconomic variables is broadly

\footnotetext{
${ }^{19}$ Differences in data coverage raise the issue of whether all regressions should be run on the maximal possible cominon set of countries, or on as many countries as possible for the particular regression. Since the in tersection of the data sets covers only 32 countries, 1 have chosen the latter approseh. I have also excluded any data series that includes less than 10 observations.

${ }^{20}$ In Fischer (1992), in a similar table, only the inflation rate and the budget surplus were significantly correlated with the growth rate. The change is a result of the increase in sanple sizes since that paper was written. I have also substituted the moving average measure of in flation for the standard deviation of the in flation rate over the entiro period (SINFLAT) in equation (10), for comparability with the panel regressions. The coeflicient on SINFLAT in the anslog of equation (10) is -0.026 , with - 1-statistic of $\mathbf{- 2 . 3 4}$.

${ }^{21}$ They are: Ghana, Cote d'Ivoiro, Kenya, Malawi, Morocco, Zambia, Dominican Republic, Jamaica, Mexico, Argen lina, Chile, Colombia, Ecuador, Paraguay, Venezuela, India, Indonesia, Korea, Pakistan, Thailand, Greece, Turkey.

${ }^{22}$ As noted above, the high correlation between the inflation rato and its standerd doviation preclude the inclusion of both variables in the regressions.
} 
consistent with prior expectations. However, in using only period averages, the cross-sectional regressions discard the information in the time series for individual countries. The results of similar panel regressions are presented in Table 4.

The simple panel regressions in Table 4 (equations (12) to (16)) confirm the relationships between inflation and inflation variability, ${ }^{\nu}$ and growth, and also between the budget surplus and growth, seen in Table 3. In the time series, the black market exchange premium correlation with growth is lower than in the cross section, while the correlation between changes in the terms of trade and growth is increased; improvements in the terms of trade are associated with higher growth. The numerical value of the coefficient on inflation in equation (12) is a bit higher than that in equation (6), while the coefficient on the standard deviation of inflation falls between the cross-section and the time serics. The coefficient on the budget surplus in equation (13) is almost double that in equation (7), possibly a result of reverse causation between growth and the budget within the time series for individual countries.

Regression (17) includes all the regressors except inflation uncertainty. All the coeflicients are significantly different from zero. They imply that a country that has an inflation rate 100 percentage poinls higher than another (e.g. 110 percent per annum rather than 10 percent per annum) will have a growth rate that is 3.9 percent lower; and that a country with a budget surplus that is higher by 1 percent of GDP, will have a growth rate that is 0.23 percent larger. Countries with higher black market exchange premia grow more slowly. The units ${ }^{24}$ imply that the black market premium in the country where it was largest, Mozanbique, would be associated with a reduction in the growth rate of 2.5 percent. Adverse changes in the terms of trade reduce growth, though the coefficient is small relative to the range of the change in the terms of trade. Sinitur regressions that include regional dummies give almost identical coefficients on the macrocenomic variables.

The regressions reported in Table 4 reinfore the evidence in favor of the vicw that macrocconomic stability, as measured by the (inverse of the) inflation rate, and indicators of macroeconomic policy like the budget surplus and the black market exchange premium, are associated with higher growth and are on average

\footnotetext{
${ }^{23}$ Values of SMAPI in this sample range from 1.8 (South Africa) to 44.5 (Bolivia). The regression implies that the high inflation variability in Bolivia would reduce its growth 2.7 percentage points relative to South Africa.

${ }^{24}$ The black market exchange premium enters the equation in the form $\ln (1+E X C H P R E M)$.
} 
good for growth. We turn now to the mechenisms through which the macroeconomic variables affect growth.

\section{Capital Accumulation}

Pursuing the approach described in Section III, we start with cquations in which the rate of capital accumulation is regressed on the same macroeconomic variables as in Tables 3 and 4 . The results presented iu Table 5 are all for panel regressions estimated by GLS. (Results for the corresponding cross-section regressions will be discussed below.) In the simple regressions (18) through (22) alt the coefficicnts are significantly different from zero, and all have the expected sign.

In regression (23), the coefficients on the in Ration rate and the black market cxichangc premiunı arc significantly different from zero, while surprisingly the budget surplus and the tcrms of trade coefficicnts lose their significance. The coefficient on inflation implies that an increase in the inflation rate by 100 percentage points (e.g. from 10 to 110 percent per annum) reduces the growth rate of the capital stock by 3.7 percentage points. This is a large effect: if the investment rate is about 20 percent of GDP, and the capital output ratio is 2.5 , then the growth rate of capital is 8 percent. According to the regression, capital in such a country would stop growing when the inflation rate reaches about 210 percent per annum. The point cstimate of the coefticicnt on the budget surplus implies that an increase in the budget deficit of 1 percent of GDP would reduce the growth rate of capital by 0.08 percentage points. Again assuming a capital output ratio of 2.5 , the investment share in GNP would decline by 0.2 percentage points. This estimate implies a relatively low level of crowding out on average. The effect implied in the one variable regression (19) is above 0.5 percentage points. The coefficient on the black market premium again suggests that it has quite large effects on investment and capital accumulation.

In single-variable cross-sectional regressions corresponding to those in Table 5 , the coufficicnts on al] variables except the terms of trade are significantly dilfercnt from zcro, and all are of the same sign as in Table

5. However, the coefficients are generally larger than in Table 5 . In the overall cross-sectional regression, corresponding to equation (23), the coefficient on the inflation rate is insignificant, while that on the dcficit becomes larger (0.50) and strongly significant.

These results suggest that one important route through which inflation affects growth is by reducing capital 
accumulation; ${ }^{2 s}$ similarly, an increase in the black market exchange prcmium, which reflects foreign exchange controls and expectations of devaluation, reduces capital accumulation. An increase in the budget surplus is associated with more capital accumulation, but the effect is not significant even at the 10 percent level. The numerical values of the coefficients are plausible, even though these cannot be thought of as structural regressions.

\section{Productivity_Growh}

The impacts of the macroeconomic variables on productivity growth estimated by the Solow residuat are presented in Table 6 . The inflation rate is significantly negatively correlated with the rate of productivity growth, with a coefficient which implies that an increase in the inflation rate by 100 percent is associated with a decline in the rate of productivity growth of 1.8 percent per annum. Increases in the budget surplus, and improvements in the terms of trade, are associated with improvements in productivily growth. The effect of inflation is robust to the inclusion of other variables. The black market exchange rate premium is significantly negatively correlated with the rate of productivity growth, but the coefficient on the black market premium loses its significance in the multiple regression.

Theories in which inflation distorts price signals suggest that uncertainty about inflation should have an impact on productivity. The negative coefficient on the standard deviation of inflation (SMAPI) in equation (29) is consistent with this view, but the coefficient is not statistically significant.

In the cross-sectional regressions equivalent to (24) to (28), none of the coefficients in any of the single variable regressions were significantly different from zero. This implies that the significant correlations in Table 6 are mainly a result of the time series variation between the regressors and productivity growth. In the overall regression equivalent to (29), the coefficients on inflation and the budget surplus were similar to those in (29), but again not statistically significant.

\footnotetext{
${ }^{25}$ De Gregorio (1993) also finds strong effects of in lation on investnent.
} 


\section{Labor Force Growth}

For the sake of completeness, Table 7 presents estimates of the panel equations for labor force growth. It would be surprising if the macroeconomic variables had a major impact on the growh of the labor force. In fact, the regressions in Table 7 show no coefficients to be significantly different from zero in the overall regression (35), and only the correlations with the exchange premium and infation variablity to be significant in the one-independent-variable regressions.

\section{Summary}

The strongest result that comes out of the regressions reported in Tables 5 through 8 is the consistent negative correlation between inflation and growth. Inflation is negatively associated with both capital accumulation, and productivity growth. There is a strong positive correlation between the budget surplus and growth, with the evidence suggesting some infucnec of the surplus on capital accumulation, and a stronger effect on the rate of growth of productivity. Adverse changes in the terms of trade reduce growth, mainly through their effect on productivity growth. The black market exchange premium is negatively related to growth, mainly through lower capital accumulation. The macroeconomic variables are not significantly associated with labor force growth.

\section{INFLATION NON-LINEARITIES AND OTHER VARIATIONS}

While it is easy to believe that triple digit inflation has adverse effects on economic growth through the mechanisms discussed in Section I, and reflected in the regressions for capital accumulation and productivity growth, it is possible that there is a range of low infation rates in which variations in infation have very little effect on growth. Thus, in testing for non-linear effects of inflation, I expect to find more significant cffects of inflation at high than at low inflation rates.

To allow for possible non-linearities in the effects of inflation, the basic regressions for growth, capital accumulation and productivity were estimated using a spline function, with breaks at 15 and 40 percent. ${ }^{26}$ In Table 8, the inflation variables enter as:

INFLL is the value of the inflation rate if it is 15 percent or less

\footnotetext{
${ }^{26}$ See Greene (1993), pp. $235-238$ for spline regressions.
} 
INFLM is the value of the inflation rate if it is between 15 percent and 40 percent

INFLH is the value of the inflation rate if it is above 40 percent

Table 8 shows the variants of panel regressions (17), (23), and (29), with the inflation rate broken inlo three categories. The results show that the effects of inflation are non-linear, but that, per percentage point of inflation, the association between inflation and growth and its determinants on average weakens as inflation rises. ${ }^{n}$ It is thus not the case, as I had expected, that it is the high inflation outliers that are responsible for the overall negative correlations between inflation and growth, capital accumulation, and productivity growth, secn in Tables 5 through 7. Rather the association betwecn inflation and growth, and inflation and capita] accumulation, is stronger at the low and moderate inflation levels than at high inflation. When inflation is decomposed as in Table 8 , none of the inflation components in equation (38), the equation for productivity growth, is significant, even though inflation enters significantly in the corresponding linear equation (23).

Note also that when the inflation rate is decomposed in this way, the coefficient on the budget surplus in the capital accumulation equation becomes statistically significantly different from zero. An increase in the budget deficit is statistically significantly associated in lable 8 with lower growth through bolh lower capital accumulation and lower productivity growth.

The results in Table 8 suggest that the basic nonlinearity in the relationship between inflation and growh could be captured by a function in which $\log (1+\pi)$ appears. When regressions like (17). (23) and (29) are run with $\log (1+\pi)$ replacing the inflation rate, the $t$-statistic on the inflation variable rises in each case, and the remaining coefficients are little affected.

Inflation Uncertainty: Grier and Tullock (1989) report a significant negative association between inflation variability and growth, and a relationship between inllution and growth that varies across regions. Tables 3-6 show the simple relationship between the moving standard deviation of inflation (SMAPI) and the dependenl variables. In all cases, the direction of the relationship is the same as that between inflation and the dependent variable.

Both the inflation rate and SMAPl have been included in several regressions, to try to separate out the

\footnotetext{
${ }^{27}$ Levine and Zervos (1992) obtain similar results.
} 
effects of high from uncertain inflation. No consistent pattem of results emerged. In the panel regressions, both with and without the other variables in the regression, the coefficient on the inflation rate was almost always negative, and that on the standard deviation measurcs was sometimes negative and more often positive, sometimes significantly so.

The Standard Variables: In Table 9 I report the results of adding the standard cross-country variablcs to regressions (17), (23) and (29). These all enter as period averages or initial values. lnitial real GNP per capita enters the growth and capital accumulation equations significantly and negatively; a measure of tariff protection opensess, defined as the product of the volume of trade relative to GNP and the tariff rate, affects productivity growtb negatively; and the human capital measure is estimated to increase capital accumulation. The measure of financial intermediation does not enter any of the equations significantly.

The most important result in Table 9 is that the addition of these variables leaves the basic relationships between the dependent and macro-policy variables unchanged.

\section{V1. CAUSALITY}

While inflation is negatively associated with growth and with its production function determinants, it is not clear -- especially in the panel regressions -- which way the causation runs. If supply shocks predominate, then possibly adverse supply shocks cause both inflation and slower growth, and the regrcssions may mert]y be reflecting that association.

The inclusion of changes in the terms of trade as a regressor goes a long way towards dealing with this problem. For most of the developing countries, changes in the terms of trade are a major sourcc of supply shocks, and these have been taken into account in the multi-variable regressions in Sections IV and V. The usc of measures of central bank independence as instruments for inflation in the cross-sectional regressions, as in Cukierman et al (1992) provides another method of dealing with the endogeneity of inflation. Their results suggest that the causation runs significantly, but not cxclusively, from inflation to growth.

Sub-period Regressions: In addition, 1 have split the period up into two parts, from 1960 to 1972, and from 1973 to 1988.2 Demand shocks probably predominated in the first period, and supply shocks in the second. If

\footnotetext{
${ }^{28}$ Michel Bruno suggested this approach.
} 
supply shocks are primarily responsible for the negative association between inflation and growth, we should expect the negative association to be stronger in the second period than in the first, where we might even expeec to find a positive association.

Table 10 shows the results of this breakdown, presenting only the coefficient on intlation from the multiple regressions corresponding to

(17), (23) and (29). In the simple regressions, (42) to (47), the coefficient on inflation is always negativc, and absolutely larger in the first period than in the second. The t-statistics are always lower for the first period. Similarly, in the multiple regressions, the absolute value of the coefficients is larger in the first period than in the second, but there are much fewer degrees of freedom and the t-statistics are smaller.

The breakdown into sub-periods thus strengthens the view that the relationship betwcen inflation and growth is not merely a result of supply shocks.

\section{SOME RESERVATIONS}

The results so far support the conclusions that high inflation, large budget deficits, and cxchange market distortions, are associated with lower growth. Most of the results suggest also that these rclationships are to some extent causal. The positive association between the budget surplus and growth appears particularly robust, and that between the black market exchange premium and growth is also strong. Thus, the evidence from the regressions and from case studies is consistent with the view that the causation is not fully from low growth to high inflation, and therefore that countries that are able to reduce the inflation rate in a sustainable way can on average expect higher growth to follow. There is nothing in the results to contradict the view that inflation is merely a symptom of a govemment out of control -- but there is nothing in that argument that contradicts the view that controlling inflation will help restore growth.

While the regressions provide suggestive evidence, it is also uscful to look at the exceptions. Table 11 shows that some countries have experienced rapid growth at high inflation rates. During the period 1961-88, at least fourteen countries in the World Bank database experienced an annial inflation rate greater than 50 percent in at least one year. Growth in some of these countries exceeded 5 percent during a year or more of the 50 percent or more inflation. Table 11 lists those cases, as well as information about growth and inflation during the entire period of high inflation of which the high growth period is a part. 
Similarly, treating the budget deficit as a macroeconomic indicator, the 15 countries in Table 12 have experienced deficits in excess of 10 percent of GDP during the periods shown. Some of them, including Brazil and Israel, are also listed in Table 10. Others listed in Table 12, include rapid growers such as Morocco during the period 1976-79. 30

The data presented in Tables 11 and 12 raise the question of the circumstances under which countries can continue to grow fast when such standard indicators of the macrocconomic situation as the deficit and inflation are exceptionally high. Every country that appears in Table 11 ran into severe trouble at some later stage. Thus Table 11 seems to show only that rapid growth is possible for a time even with high inflation. In some cases, such as Peru, the period of rapid growth is associated with a rapidly accelerating inflation and situation that is heading rapidly for disaster.

By drawing the line in Table 11 at 50 percent inflation, I omit those countries that have succecded in growing over sustained periods with inflation that persisted in the moderate range of $15-30$ percent, typically with the assistance of extensive indexation." Such situations are sustainable, provided the govemment takes action to prevent inflation rising above the 30 percent range. The explosive situations appear to be those in which govemments believe the inflation rate is of no major consequence, and permit it to continue rising even after it leaves the moderate range.

The data in Table 12 provide a much less clear lesson. For most of the countries in the tuble, growth rates were low during the periods of high deficits, but Moroceo grew fast during the high deficil period, as did Italy in the 1980 s. It is clearly possible to sustain large deficits for some time, with the assistance of high saving rates and financial repression. Notice though that inflation rates are low for almost all the non-Latin American high deficit countries. The lesson seems to be that a high deficit by itself is not a certain indicator of later trouble. It may be sustainable for a while, and it may be consistent with low inflation. It would take supplementary studies of the budgetary situation and debt dynamics to detcrmine whether a large deticit is

\footnotetext{
${ }^{29}$ For countries for which the Easlerly fiscal data are available, the data listed in Table 12 are from thal source; for other countries for which IMF deficit data are available (indicaled by an *), that is the source.

${ }^{30}$ Industrialized countries such as Italy are not included in the dalabase from which Table 12 is drawn.

${ }^{31}$ See Dombusch and Fischer (1993).
} 
sustainable -- and therefore consistent with macroeconomic stability -- or unsustainable, and thereforc a harbinger of macroeconomic instability.

\section{CONCLUDING COMMENTS}

The broad range of evidence reviewed and presented in this paper supports the conventional viciv that a stable macroeconomic environment, meaning a reasonably low rate of inflation and a small budget deficit, is conducive to sustained cconomic growth. The growth accounting framework makes it possible to idcntify the main channels through which inflation reduces growth. As a grcat deal of prior theory predicts, the results presented here imply that inflation reduces growth by reducing investment, and by reducing the ratc of productivity growth. Larger budget surpluses are also strongly associated with more rapid growth, through greater capital accumulation and greater productivity growth. An undistorted foreign exchange market is also conducive to growth.

The cross-sectional regression methodology that is associated with the new growth theory has been extended in this paper to include panel regressions, whose results typically reinforce those of the simplc crosssections. The endogeneity issue is difficult to deal with formally, but the weight of the evidence implies that the relationship between inflation and growth is not purely a result of low growth producing high inflation. The evidence that small deficits are good for growth is strong, as is the support for the view that distorted foreign exchange markets, as reflected in a large foreign exchange market premium, are bad for growth.

The examples presented in Tables 11 and 12 show that low inflation and small deficits are not necessary for high growth, over even quite long periods. They do imply that very high inflation is not consistent with sustained growth. The results also suggest that the sustainability of the budget delicit has to be investigated in more detail than is possible in the aggregative approach that has been taken in this paper.

To make further progress in defining a stable and sustainable macroeconomic framework, and in clarifying the channels through which macroeconomic variables affect growth, it will be necessary to undertake more detailed case studies of individual countries, based on structural models. A good start on this approach has already been made in some of the contributions in Little et $\underline{\text { gl }}$, and in many studies of individual countries. The conlusions of those studies agree with the conclusions in this paper. 


\section{BIBLIOGRAPHY}

Aizenman, Joshur, and Nancy Marion (1991). "Macrocconomic Uncertainty, Persistence and Growth", nimeo, Dartmouth College, December.

Barro, Robert J. (1991). "Economic Growth in a Cross Seetion of Countries", Quarterly Journal of Economics, 106, 2 (May), 407-444.

Chenery, Hollis B., Sherman Robinson and Moshe Syrquin (1986). Industrialization and Growth. New York: Oxford University Press.

Corden. Max (1990). "Macroeconomic Policy and Growth: Some Lessons of Experience", Proceedings of the World Bank Annual Conference on Development Economics, 59-84.

Cukierman, Alex, Pantelis Kalaitzidakis, Lawrence H. Summers and Steven B. Webb (1992). "Central Bank Indpendence, Growth, Investment, and Real Rates", presented at Camegie-Rochester Conference on Public Policy, November.

De Gregorio. Jose (1993). "Inflation taxation, and long-run growth", Joumal of Monetary Eiconomics, 31,3 (June), 271-298.

Dellas, Harris (1990). "Stabilization Policy and Long Term Growth: Are They Related? A Darwinian Perspective", mimeo, University of Maryland.

De Long, J. Bradford and Lawrence H. Summers (1991). "Equipment Investnent and Economic Growth", Quarterly Joumal of Economics, 106, 2 (May), $369-406$. 
-...- (1992). "Macroeconomic Policy and Long-Run Growth", Federal Reserve Bank of Kansas City Economic Review, 77, 4 (fourth quarter), 5-30.

Dombusch, Rudiger and Stanley Fischer (1993). "Moderate Inflation", World Bank Economic Observer, 7, 1 (Jan), $1-44$.

Easterly, William and Sergio Rebelo (1992). "Fiscal Policy and Growth: An Empirical Investigation", numeo, World Bank.

Elias, Victor J. (1992). Sources of Growth. San Francisco: ICS Press.

Fischer, Stanley (1983). "Inflacion y Crecimiento," (Inflation and Growth), uadernos $\underline{\mathrm{d}}$ Economia, 20, (Dec), 267-278. (Sidrauski Memorial Lecture, in English as NBER Working Paper \#1235.)

...... (1991). "Macroeconomics, Development, and Growth", NBER Macrocconomics Annual, 329-364.

(1992). "Growth: The Role of Macroeconomic Factors", mimeo, MIT.

and Franco Modigliani (1978). "Towards an Understanding of the Real Effects and Costs of Inflation",

Welwirtschaftliches Archiv 810-832. (Reprinted in S. Fischer, Indexing. Inflation, and Economic Growth, MIS Press, 1986).

Greene, William H. (1993). Econometric Analysis. New York: Macmillan.

Grier, Kevin B. and Gordon Tullock (1989). "An Empirical Analysis of Cross-National Economic Growth, 195180", Joumal of Monetary Economics, 24, 2 (Sept), 259-276. 
Gylfason, Thorvaldur (1991). "Inflation, Growth, and Extcmal Debt: A View of the Landscape", The World Economy, 14, 3 (Sept), 279-298.

Hamilton, James D. and Marjorie A. Flavin (1986). "On the Limitations of Government Borrowing: A Framework for Empirical Testing", American Economic Review, 76. 4 (Sept), 808-819.

Kormendi, Roger C. and Philip G. Meguire (1985). "Macroeconomic Determinants of Growth: Cross-Country Evidence", Journal of Monetary Economics, 16, 2 (Sept), 141-64.

Levine, Ross and David Renelt (1992). "A Sensitivity Analysis of Cruss-Country Growth Regrcssions", American Economic Review, 82, 4 (Sept), 942-963.

...-... and S. Zervos (I992). "Looking at the Facts: What We Know about Policy and Growth from CrossCountry Analysis", mimeo, World Bank (October).

Little, Ian, Richard Cooper, Max Corden, and Sarath Rajapatirana (1992). Boom Crisis and Adjustment: The Macroeconomic Experience of Developing Countries, mimeo.

Lucas, Robert E. (1973). "Some Intemational Evidence on Output-Inflation Tradeoffs", American Economic Review, 63 (June), 326-334.

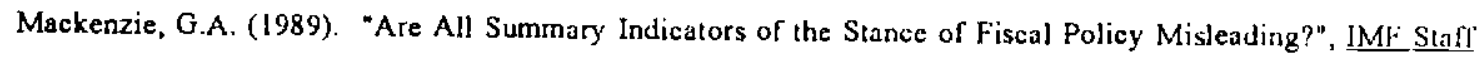
Papers, 36, 4 (Dec), 743-770.

Mankiw, N. Gregory, David Romer, and David N. Weil (1992). "A Contribution to the Empirics of Economic Growth", Quarterly Joumal of Economics, 107, 2 (May), 407-438. 
Morris, Cynthia T. and Ima Adelman (1988). Comparative Patlerns of Economic Development $1850-1914$.

Baltimore: Johns Hopkins Press.

Pindyck, Robert and Andres Solimano (1993). Title to be provided, NBER Macroeconomics Annual,

fortheoming.

Romer, Paul M. (1989). "Human Capital and Growth: Theory and Evidence", NBER Working Paper \#3173.

Solimano, Andres (1989). "How Private Investment Reacts to Changing Macroeconomic Conditions: The Case of Chile in the Eighties", World Bank Working Paper WPS 212.

World Bank (1989). "Adjustment Lending: An Evaluation of Ten Years of Experience", Policy and Rescarch Series Paper

World Bank (1990). "Adjustment Lending Policies for Sustainable Growth", Policy and Research Series Paper $\$ 14$.

(1991). World Development Report.

(1992). "The Third Report on Adjustment Lending: Private and Public Resource for Growth", March. 
TABLES

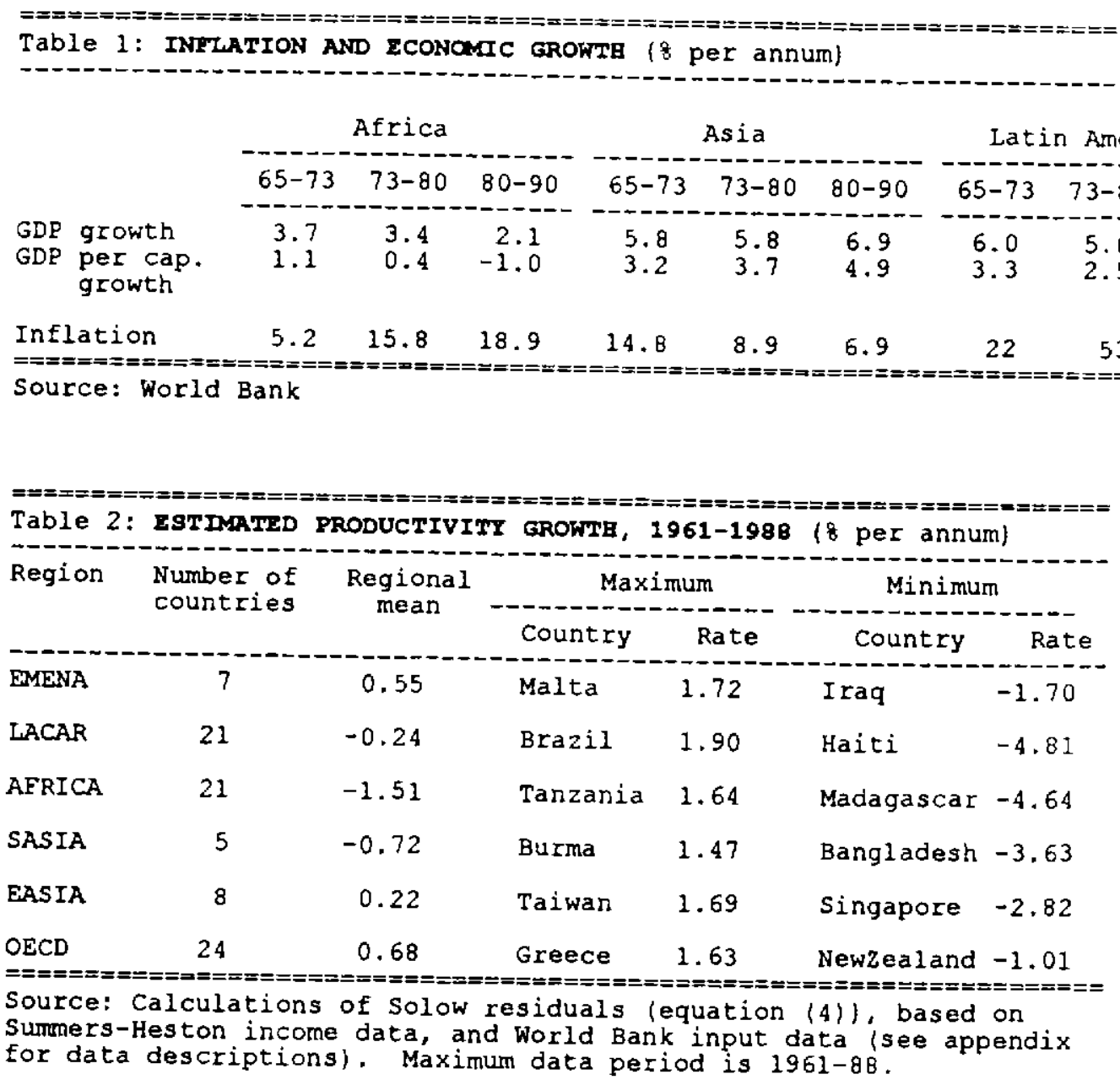




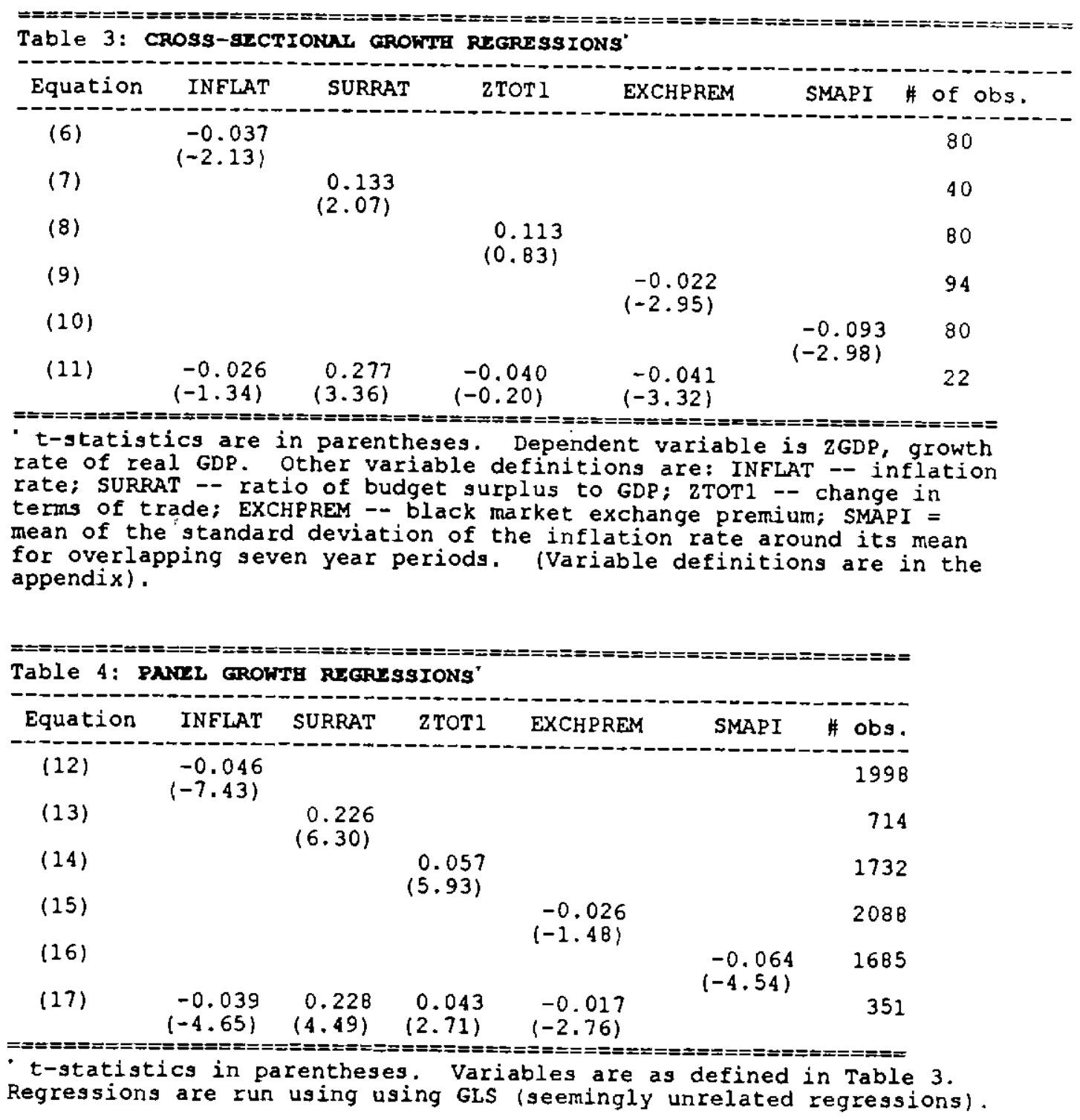




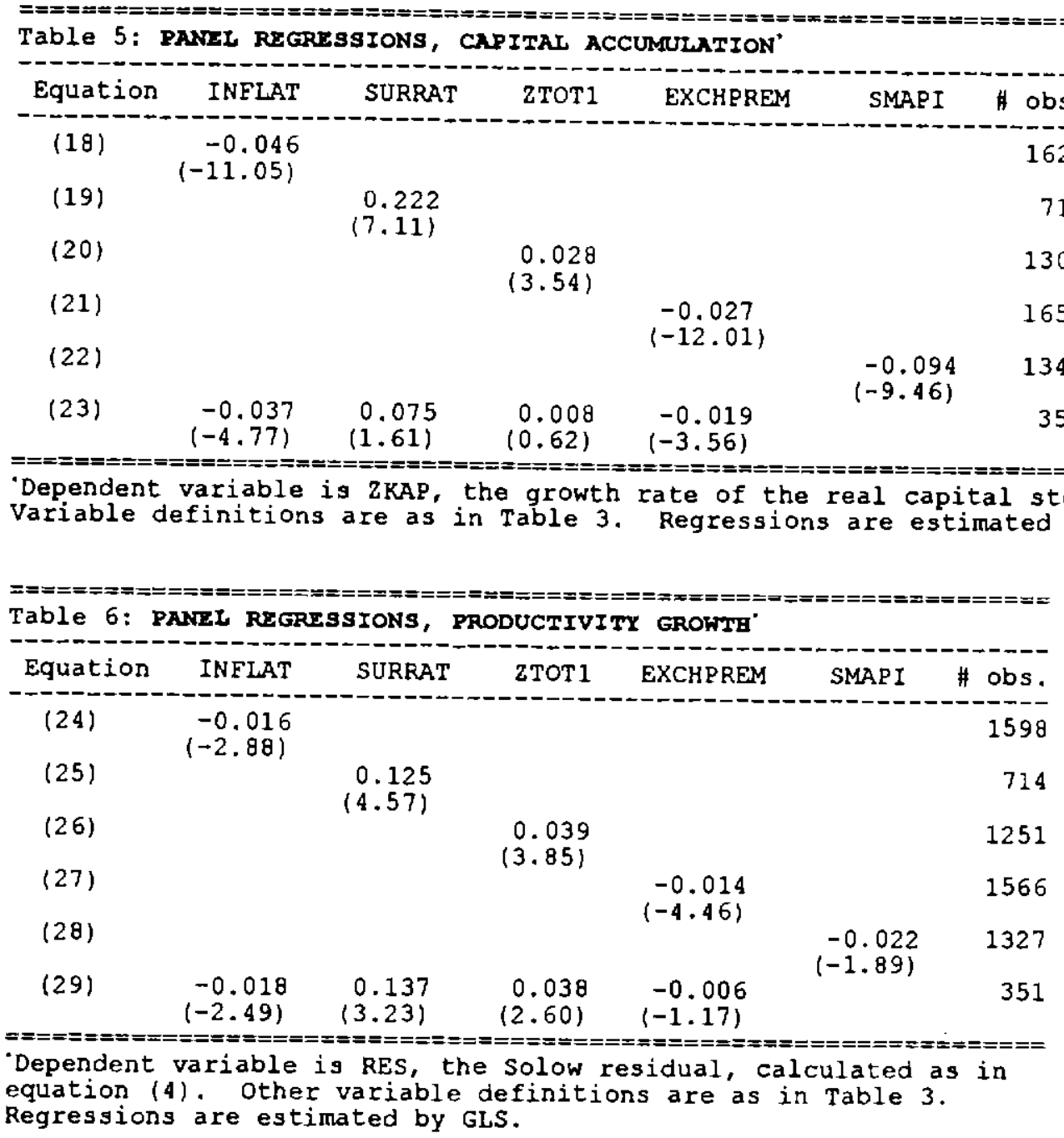




\begin{tabular}{|c|c|c|c|c|c|c|}
\hline Equation & INELAT & SURRAT & ZTOT1 & EXCHPREM & SMAP I & \# obs. \\
\hline$(30)$ & $\begin{array}{r}0.001 \\
(1.75)\end{array}$ & & & & & 2021 \\
\hline (31) & & $\begin{array}{l}-0.0015 \\
(-0.14)\end{array}$ & & & & 726 \\
\hline$(32)$ & & & $\begin{array}{l}-0.0007 \\
(-0.64)\end{array}$ & & & 1668 \\
\hline$\{33\}$ & & & & $\begin{array}{l}0.0009 \\
(2.60)\end{array}$ & & 2020 \\
\hline$\{34\}$ & & & & & $\begin{array}{r}0.003 \\
\{2.57\rangle\end{array}$ & 1669 \\
\hline (35) & $\begin{array}{r}-0.002 \\
(-1.14)\end{array}$ & $\begin{array}{l}-0.007 \\
(-0.53)\end{array}$ & $\begin{array}{l}0.0009 \\
(0.29)\end{array}$ & $\begin{array}{l}0.0003 \\
(0.22)\end{array}$ & & 352 \\
\hline
\end{tabular}

$========= \pm===== \pm======= \pm==0$ Dependent variable is $2 L A B$, the growth rate of the labor force. Regressions are estimated by GLS.

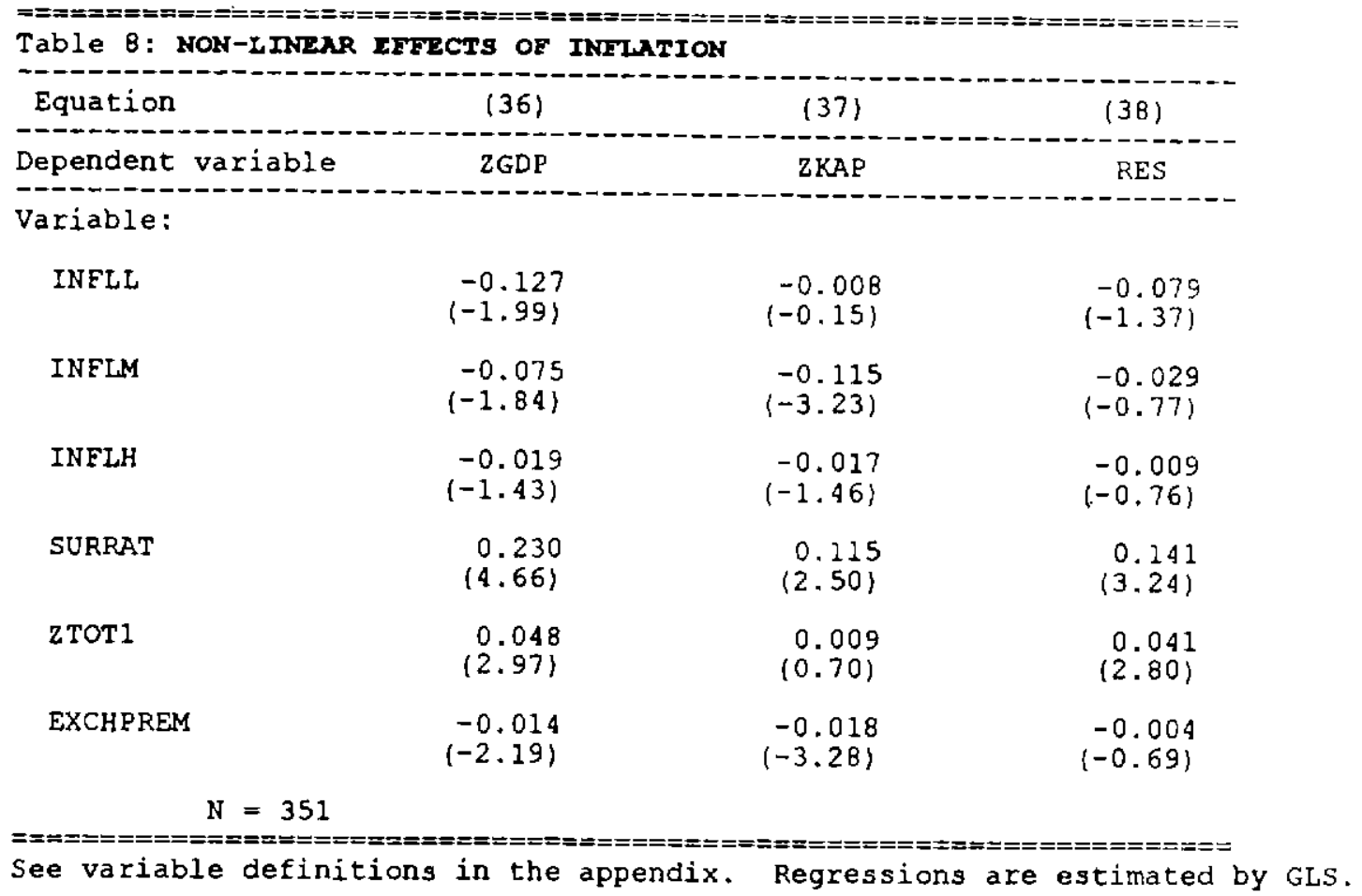




\begin{tabular}{|c|c|c|c|}
\hline Equation & $(39)$ & $(40)$ & $(41)$ \\
\hline Dependent variable & ZGDP & ZKAP & RES \\
\hline \multicolumn{4}{|l|}{ Variable: } \\
\hline INELAT & $\begin{array}{l}-0.031 \\
(-2.72)\end{array}$ & $\begin{array}{l}-0.032 \\
(-4.21)\end{array}$ & $\begin{array}{l}-0.017 \\
(-1.59)\end{array}$ \\
\hline SURRAT & $\begin{array}{r}0.241 \\
(3.00)\end{array}$ & $\begin{array}{c}0.038 \\
(0.61)\end{array}$ & $\begin{array}{r}0.146 \\
(2.04)\end{array}$ \\
\hline ZTOT1 & $\begin{array}{r}0.066 \\
(3.39)\end{array}$ & $\begin{array}{c}0.002 \\
(0.13)\end{array}$ & $\begin{array}{c}0.063 \\
(3.41)\end{array}$ \\
\hline EXCHPREM & $\begin{array}{l}-0.015 \\
(-1.94)\end{array}$ & $\begin{array}{l}-0.014 \\
(-2.72)\end{array}$ & $\begin{array}{l}-0.007 \\
(-1.08)\end{array}$ \\
\hline $\ln (\mathrm{GNPO})$ & $\begin{array}{l}-0.021 \\
(-2.18)\end{array}$ & $\begin{array}{l}-0.035 \\
(-2.55)\end{array}$ & $\begin{array}{l}-0.007 \\
(-0.82)\end{array}$ \\
\hline OPENTAR & $\begin{array}{l}-0.003 \\
(-1.27)\end{array}$ & $\begin{array}{l}-0.0002 \\
(-0.06)\end{array}$ & $\begin{array}{l}-0.003 \\
(-2.13)\end{array}$ \\
\hline BHKAVG & $\begin{array}{r}0.005 \\
(1.44)\end{array}$ & $\begin{array}{c}0.013 \\
(2.72)\end{array}$ & $\begin{array}{l}0.0001 \\
(0.03)\end{array}$ \\
\hline LLY & $\begin{array}{l}-0.020 \\
(-0.36)\end{array}$ & $\begin{array}{l}-0.039 \\
(-0.50)\end{array}$ & $\begin{array}{l}-0.016 \\
(-0.35)\end{array}$ \\
\hline \multicolumn{4}{|c|}{$\begin{array}{l}\text { GNPO is Summers-Heston } 1960 \text { per capita GNP; OPENTAR is a measure of } \\
\text { tariff protection, equal to ( }(\mathrm{X}+\mathrm{M}) / 2 \mathrm{GDP}) \mathrm{ln}(1+\mathrm{tar} \text { ) where } \mathrm{X} \text { and } \mathrm{M} \text { are } \\
\text { exports and imports, and tar is the WDR measure of tariffs and other } \\
\text { surcharges on imports; BHKAVG is the Barro-Lee measure of human } \\
\text { capital; and LLY (from Levine and Zervos, 1992) is the average ratio } \\
\text { of liquid liabilities to GDP for the period } 1960-89 \text {. }\end{array}$} \\
\hline
\end{tabular}




\begin{tabular}{|c|c|c|c|c|c|c|}
\hline \multirow{2}{*}{$\begin{array}{l}\text { Dependent variable } \\
\text { Period }\end{array}$} & \multicolumn{2}{|c|}{ ZGDP } & \multicolumn{2}{|c|}{ ZKAP } & \multicolumn{2}{|c|}{ RES } \\
\hline & $61-72$ & $73-88$ & $61-72$ & $73-88$ & $61-72$ & $73-88$ \\
\hline Equation & $(42)$ & (43) & $(44)$ & $(45)$ & $(46)$ & $(47)$ \\
\hline \multicolumn{7}{|l|}{ Simple regression: } \\
\hline INELAT & $\begin{array}{l}-0.072 \\
(-3.74)\end{array}$ & $\begin{array}{r}-0.033 \\
-(4.67)\end{array}$ & $\begin{array}{r}-0.052 \\
-(3.46)\end{array}$ & $\begin{array}{l}-0.026 \\
(-6.30)\end{array}$ & $\begin{array}{c}-0.032 \\
(-1.47)\end{array}$ & $\begin{array}{l}-0.013 \\
(-2.16)\end{array}$ \\
\hline \# of obs. & 773 & 1225 & 631 & 995 & 640 & 958 \\
\hline Equation & $(48)$ & $(49)$ & $(50)$ & (51) & $(52)$ & (53) \\
\hline \multicolumn{7}{|l|}{ Multiple regression: } \\
\hline INEIAT & $\begin{array}{r}-0.200 \\
(-3.37)\end{array}$ & $\begin{array}{r}-0.039 \\
-(4.04)\end{array}$ & $\begin{array}{r}-0.031 \\
-(0.69)\end{array}$ & $\begin{array}{l}-0.029 \\
(-3.40)\end{array}$ & $\begin{array}{l}-0.173 \\
\{-3.09\}\end{array}$ & $\begin{array}{r}-0.019 \\
(-2.33)\end{array}$ \\
\hline \# of obs. & $=======$ & $========$ & 44 & 306 & 44 & 306 \\
\hline
\end{tabular}

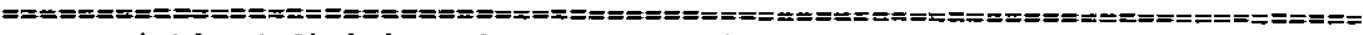
See variable definitions in the appendix. Regressions are estimated by GLS.

\begin{tabular}{|c|c|c|c|c|c|c|}
\hline \multirow[t]{2}{*}{ Country } & \multicolumn{3}{|c|}{ High growth period } & \multicolumn{3}{|c|}{ Entire spell } \\
\hline & Period & Inflation & GNP growth & Period & Inflation & GNP grawth \\
\hline Argentina & $\begin{array}{l}1977 \\
1979 \\
1986\end{array}$ & $\begin{array}{r}101.5 \\
95.4 \\
64.5\end{array}$ & $\begin{array}{l}6.2 \\
6.8 \\
5.3\end{array}$ & $1975-87$ & 112 & 0.5 \\
\hline Brazil & $\begin{array}{l}1980 \\
1984-86\end{array}$ & $\begin{array}{r}60.3 \\
105.3\end{array}$ & $\begin{array}{l}8.7 \\
7.1\end{array}$ & $1980-87$ & 90 & 3.5 \\
\hline Chile & 1977 & 65.2 & 9.4 & $1972-77$ & 115 & -1.2 \\
\hline Ghana & 1978 & 54.9 & 9.4 & $1977-78$ & 66 & 5.6 \\
\hline Israel & $1979-80$ & 70.3 & 6.0 & $1979-85$ & 95 & 3.8 \\
\hline Peru & $\begin{array}{l}1979 \\
1986-87\end{array}$ & $\begin{array}{l}51.1 \\
59.8\end{array}$ & $\begin{array}{l}5.6 \\
7.9\end{array}$ & $\begin{array}{l}1979 \\
1983-87\end{array}$ & $\begin{array}{l}51 \\
73\end{array}$ & $\begin{array}{l}5.6 \\
2.4\end{array}$ \\
\hline Uganda & $\begin{array}{l}1981 \\
1988\end{array}$ & $\begin{array}{r}73.6 \\
104.3\end{array}$ & $\begin{array}{l}8.0 \\
6.3\end{array}$ & $\begin{array}{l}1981 \\
1985-88\end{array}$ & $\begin{array}{r}74 \\
102\end{array}$ & $\begin{array}{l}8.0 \\
0.1\end{array}$ \\
\hline
\end{tabular}




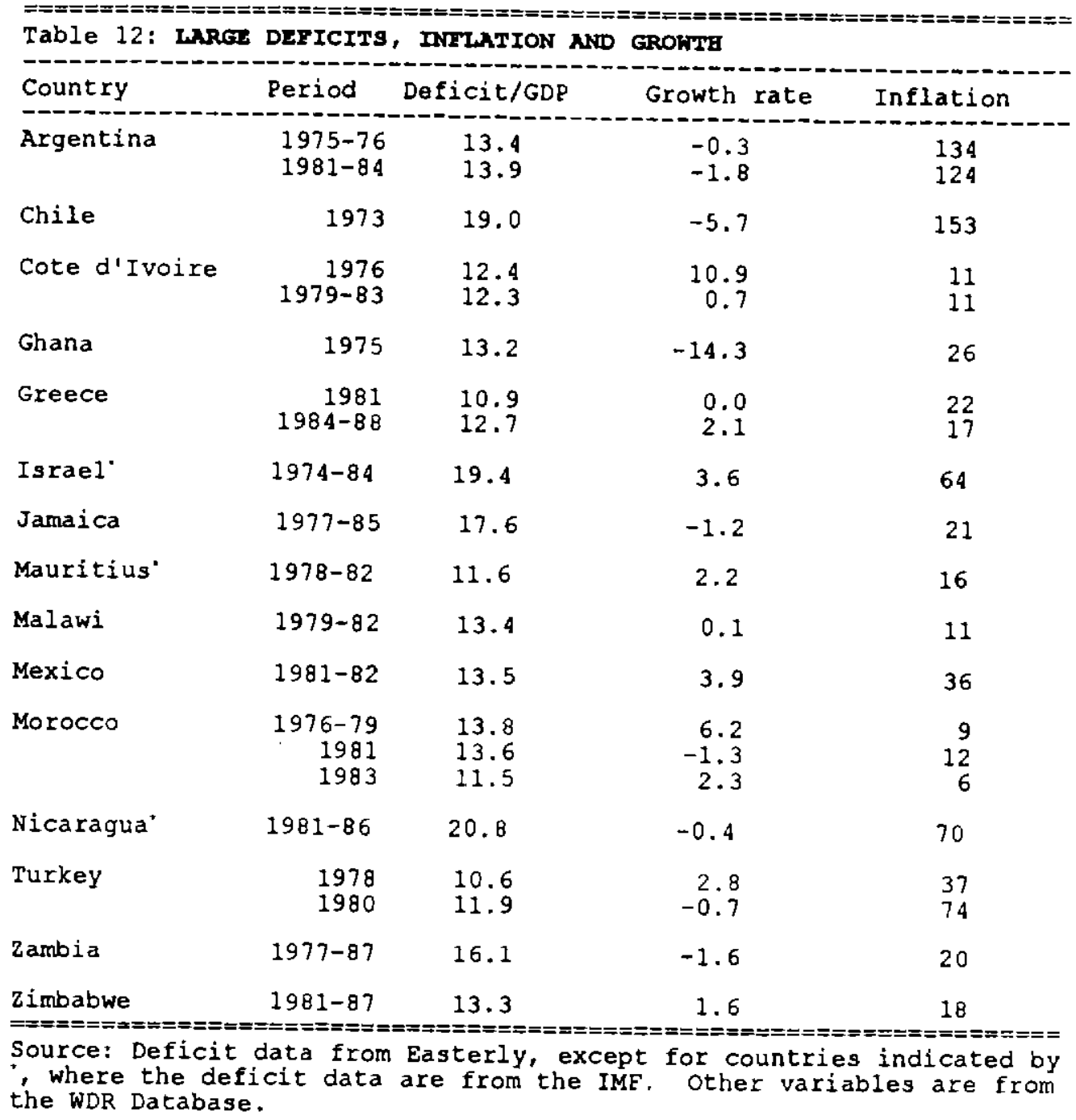


All time series that have less than ten observations have been excluded from regressions.

ZGDP is the log-difference of real GDP, as estimated by Heston and Summers.

ZKAP is the growth of the capital stock, using the World Bank (Nehru) data set. The data start with an assumed capital stock of zero in 1950, which leads to very rapid rates of growth of the capital stock in early years. Further, some estimates are based on an assumed stock of zero in 1960. All observations for which the capital stock grows by more than 30 percent per annum have been excluded.

ZLAB is the log difierence of the labor force, from the WDR dataset.

ZED is the log difference of the product of LABOR, the size of the labor force, and BHK, the Barro-Lee (1993) measure of the average years of educational attainment of the labor force. It is an estimate of the growth rate of human capital.

INFLAT is the inflation rate, computed from the CPl series in International Financial Statistics. GDP dellator data from the World Bank were used to extend inflation series for the Central African Republic, Malawi, and Chad.

SINFLAT is the standard deviation of the inflation rate over all the observations on inflation for a given country.

SMAPI is a time series estimate of inflation uncertainty, calculated as the standard deviation of the infation rate 
around its mean for overlapping seven year periods.

EXCHPREM is the black market exchange rate premium from the WDR dataset. The variable used in regressions is $\ln (1+E X C H P R M)$.

ZTOTl is the $\log$ difference of the terms of trade from the WDR dataset.

SURRAT is the budget surplus ( + ) or deficit (-) provided by William Easterly.

AFRICA, ASIA, EASIA, LACAR, OECD, and SASIA are regional dummies. 